Saint Louis University School of Law

Scholarship Commons

All Faculty Scholarship

2012

\title{
The Mutability of Public Reason
}

Chad Flanders

Saint Louis University School of Law

Follow this and additional works at: https://scholarship.law.slu.edu/faculty

Part of the Law and Philosophy Commons

\section{Recommended Citation}

Flanders, Chad, The Mutability of Public Reason (June 2012). Ratio Juris, Vol. 25, Issue 2, pp. 180-205, 2012. http://dx.doi.org/10.1111/j.1467-9337.2012.00509.x

This Abstract is brought to you for free and open access by Scholarship Commons. It has been accepted for inclusion in All Faculty Scholarship by an authorized administrator of Scholarship Commons. For more information, please contact erika.cohn@slu.edu, ingah.daviscrawford@slu.edu. 


\section{The Mutability of Public Reason}

Ratio Juris, Vol. 25, Issue 2, pp. 180-205, 2012

Chad Flanders

Saint Louis University - School of Law

Date Written: June 2012

\section{$\underline{\text { Abstract }}$}

Rawls's "public reason" has not been without its critics. One criticism is that public reason is "conservative." Public reason must rely on those beliefs that are "widely shared" among citizens. But if public reason relies on widely shared beliefs, how can it change without departing from those beliefs, thus violating public reason? In part one of my essay, I introduce the conservatism objection and describe two unsatisfactory responses to it. Part two argues that there are aspects of public reason which diminish the force of the conservatism objection: first, that public reason is historical, and second, that it is mutable.

\section{Suggested Citation:}

Flanders, Chad, The Mutability of Public Reason (June 2012). Ratio Juris, Vol. 25, Issue 2, pp. 180-205, 2012. 